\title{
Self-assembled nickel cubanes as oxygen evolution catalysts
}

Received 00th January 20xx, Accepted 00th January 20xx

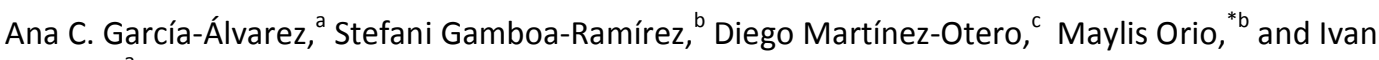 \\ Castillo*a
}

DOI: $10.1039 / \times 0 \times x 00000 x$

$\mathrm{Ni}_{4} \mathrm{O}_{4}$ cubanes $\left[\left(\mu_{3}-\mathrm{L}^{1} \mathrm{O}\right) \mathrm{NiCl}(\mathrm{MeOH})\right]_{4}(1)$ and $\left[\left(\mu_{3}-\mathrm{L}^{2} \mathrm{O}\right) \mathrm{NiCl}\left(\mathrm{H}_{2} \mathrm{O}\right)\right]_{4}$ (2) $\mathrm{L}^{1} \mathrm{OH}=1-\mathrm{H}-2$-benzimidazolylmethanol, $\mathrm{L}^{2} \mathrm{OH}=1$-methyl-2benzimidazolylmethanol) self-assemble from commercially available 1-H- and 1-methyl-2-benzimidazolylmethanol and $\mathrm{NiCl}_{2} \cdot 6 \mathrm{H}_{2} \mathrm{O}$ in high yields under mild conditions. Both complexes were characterised spectroscopically and by X-ray crystallography. The cubanes oxidise water electrocatalytically to dioxygen at neutral $\mathrm{pH}$ in aqueous potassium phosphate buffer solutions.

Catalytic water oxidation is a global challenge representing the bottleneck for water splitting, which could provide abundant fuels from renewable sources. Molecular compounds and materials that catalyse the 4-electron oxidation of water to dioxygen have benefitted from the insight gained on the structure of the $\mathrm{Mn}_{4} \mathrm{O}_{5} \mathrm{Ca}$ oxygen-evolving complex of photosystem II (PSII, Chart 1a). ${ }^{1}$ Nature accumulates four oxidising equivalents in a multimetallic-oxo cluster, and this has emerged as an appealing strategy to obtain compounds featuring metal-oxo subunits, with emphasis on complexes and materials that feature the "cubane"-type $\mathrm{M}_{4} \mathrm{O}_{4}$ motif (Chart 1b). Such clusters appear as superior alternatives to monometallic complexes, since the former may offer the synergistic action of four metal centres, without the problems inherent to the identification of well-defined active sites in heterogeneous systems that catalyse the oxygen evolution reaction (OER).

$\mathrm{M}_{4} \mathrm{O}_{4}$ structures that can be easily obtained from readily available starting materials and earth-abundant metals represent a synthetic challenge for efficient OER catalysts as renewable and sustainable energy sources, ${ }^{2}$ with artificial photosynthesis as the ultimate goal. ${ }^{3}$ The need for predictable synthetic methods has resorted to computational approaches, ${ }^{4}$ including machine learning methods. ${ }^{5}$ Although breakthroughs for the synthesis of $\mathrm{M}_{4} \mathrm{O}_{4}$ cubanes have been reported, ${ }^{2 \mathrm{a}, 6}$

\footnotetext{
a. Instituto de Química, Universidad Nacional Autónoma de México, Circuito Exterior, CU, Ciudad de México, 04510, México

${ }^{\text {b. }}$ Aix Marseille Université, CNRS, Centrale Marseille, iSm2, 13397, Marseille, France c. Centro Conjunto de Investigación en Química Sustentable UAEM-UNAM,
}

Carretera Toluca-Atlacomulco km. 14.5, Toluca, 50200, Estado de México, Mexico

Electronic Supplementary Information (ESI) available: crystallographic, spectroscopic, cyclic voltammetry, and DFT data. See DOI: 10.1039/x0xx00000x much remains to be established in the field.

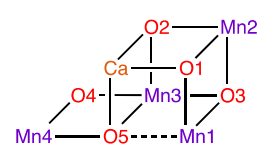

(a)

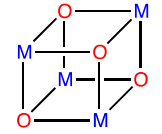

(b)

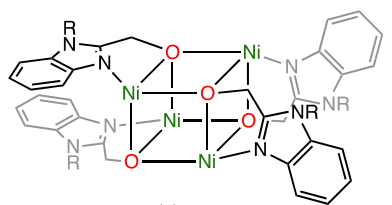

(c)
Chart 1. a) $\mathrm{Mn}_{4} \mathrm{O}_{5} \mathrm{Ca}$ cluster in PSII; b) cubane-type $\mathrm{M}_{4} \mathrm{O}_{4}$ motif; c) core of benzimidazole-derived $\mathrm{Ni}_{4} \mathrm{O}_{4}$.

In this context, the use of nickel has resulted in $\mathrm{Ni}_{4} \mathrm{O}_{4}$ structures, but benzimidazole-derived cubanes have not been tested in a rational and systematic fashion as OER electrocatalysts. $\mathrm{Ni}_{4} \mathrm{O}_{4}$ cubanes have been obtained with sterically encumbering, ${ }^{7}$ and intricate polydentate ligands. ${ }^{8}$ In contrast, 2-benzimidazolylmethanol formed in situ allowed the crystallisation of a $\mathrm{Ni}_{4} \mathrm{O}_{4}$ complex, featuring alkoxide moieties that serve as $\mu_{3}$-edges (Chart 1c). ${ }^{9 a}$ The original report focused exclusively on structural and magnetic aspects of the serendipitously obtained cubane. Rational synthesis with equimolar amounts of $\mathrm{L}^{\mathrm{n}} \mathrm{OH}$ and $\mathrm{NiCl}_{2} \cdot 6 \mathrm{H}_{2} \mathrm{O}$ affords complexes with the empirical formulae $\left[\left(\mathrm{L}^{\mathrm{n}} \mathrm{O}\right) \mathrm{NiCl}(\mathrm{S})\right]\left(\mathbf{L}^{1} \mathrm{OH}=1-\mathrm{H}-2-\right.$ benzimidazolylmethanol, $\quad \mathbf{L}^{2} \mathrm{OH} \quad=\quad 1$-methyl-2benzimidazolylmethanol; $\mathrm{S}=\mathrm{MeOH}, \mathrm{H}_{2} \mathrm{O}$, Scheme 1), in $85 \%$ $\left[\left(\mathrm{L}^{1} \mathrm{O}\right) \mathrm{NiCl}(\mathrm{MeOH})\right]$ and $63 \%\left[\left(\mathrm{~L}^{2} \mathrm{O}\right) \mathrm{NiCl}\left(\mathrm{H}_{2} \mathrm{O}\right)\right]$ yield.

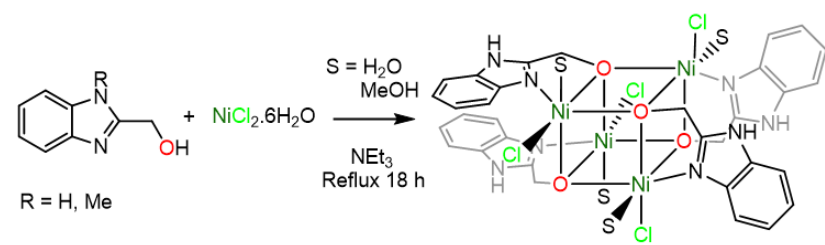

Scheme 1 Self-assembly of $\left[\left(\mu_{3}-L^{n} O\right) N i C l(S)\right]_{4}$.

Fast Atom Bombardment (FAB-MS) and/or Electrospray Mass Spectrometry (ESI-MS) revealed the presence of tetrameric aggregates in the form of $\left[\left(\mathrm{L}^{\mathrm{n}} \mathrm{O}\right)_{4} \mathrm{Ni}_{4}\right]^{+}$(presumably by reduction of the $\mathrm{Ni}^{\prime \prime}$ centres in the ionisation chamber) or $\left[\left(\mathrm{L}^{\mathrm{n}} \mathrm{O}\right)_{4} \mathrm{Ni}_{4} \mathrm{Cl}_{3}\right]^{+}$in methanolic solution, see Electronic Supporting Information (ESI) Figs. S1-S3. ${ }^{1} \mathrm{H}$ NMR spectroscopy in methanol- $d_{4}$ indicates that the cubanes are 
paramagnetic, ${ }^{8 \mathrm{a}, 9}$ based on the broad signals observed from 30 to $-15 \mathrm{ppm}$. As is often the case with $\mathrm{Ni}^{\prime \prime}$ systems with $S>1 / 2$, both complexes are ESR silent at $\mathrm{X}$-band frequency in perpendicular mode. Their optical spectra feature ligandcentred bands around $210\left(\varepsilon \sim 18-20,000 \mathrm{M}^{-1} \mathrm{~cm}^{-1}\right)$ and 274 $(18,000)$, as well as $d-d$ transitions at $675 \mathrm{~nm}(25)$ in methanol.

The cubane-type architecture of $\left[\left(\mu_{3}-\mathrm{L}^{1} \mathrm{O}\right) \mathrm{NiCl}(\mathrm{MeOH})\right]_{4}(\mathbf{1})$ and $\left[\left(\mu_{3}-\mathrm{L}^{2} \mathrm{O}\right) \mathrm{NiCl}\left(\mathrm{H}_{2} \mathrm{O}\right)\right]_{4}(2)$ was confirmed in the solid-state by $\mathrm{X}$ ray crystallography (Table S1 in ESI). Although 1 and $\mathbf{2}$ have similar structures, differences among bond lengths appear to be related to the better $\sigma$-donor properties of $\mathrm{N}$-methylated $\mathbf{L}^{2} \mathrm{OH}$, with shorter average $\mathrm{Ni}-\mathrm{N}$ distance of $2.028 \AA$ in $\mathbf{2}$ vs $2.058 \AA$ in 1 . Conversely, the average $\mathrm{Ni}-\mathrm{O}$ distance in the $\mathrm{Ni}_{4} \mathrm{O}_{4}$ framework of $\mathbf{1}$ are shorter at 2.077 vs $2.081 \AA$ in $\mathbf{2}$. The average $\mathrm{Ni}-\mathrm{O}$ distances to the exogenous $\mathrm{MeOH}$ or $\mathrm{H}_{2} \mathrm{O}$ donors are also shorter in 1 (2.092 vs $2.114 \AA$ in 2). Distortion of the cubanes is reflected in the $\mathrm{Ni}-\mathrm{O}$ lengths within the $\mathrm{Ni}_{4} \mathrm{O}_{4}$ framework, varying from 2.034(2) to 2.117(2) $\AA$ in 1, and $2.040(5)$ to $2.123(4) \AA$ in 2 . The $\mathrm{O}-\mathrm{Ni}-\mathrm{O}$ angles range from $79.36(7)$ to $82.3(1)^{\circ}$ in $\mathbf{1}$, and $79.0(2)$ to $82.5(2)^{\circ}$ in $\mathbf{2}$. All Ni-O$\mathrm{Ni}^{10}$ angles are around $99^{\circ}$ in both cases, with similar $2-2.5^{\circ}$ dispersion (Fig. 1). Comparison with the analogous cubane featuring $\mathbf{L}^{1} \mathrm{OH}$ reveals similar metric parameters. ${ }^{9}$ In contrast, a related cubane featuring 2-(hydroxymethyl)pyridine ligands is less distorted, ${ }^{11}$ as reflected in the smaller dispersion of bond lengths and angles around the $\mathrm{Ni}_{4} \mathrm{O}_{4}$ core. A significantly longer average $\mathrm{Ni}-\mathrm{N}$ distance to the pyridine donors at $2.070 \AA$
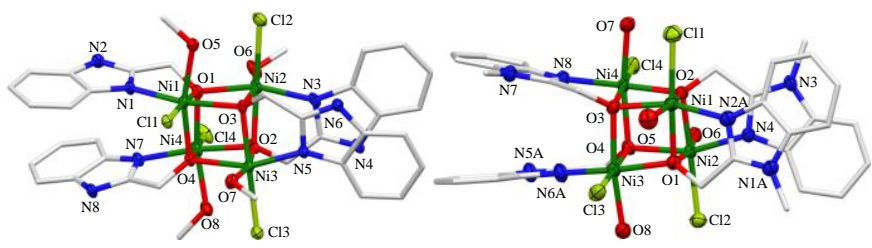

was determined.

Fig. 1 Mercury diagrams of $\mathbf{1}$ and $\mathbf{2}$ at the 50\% probability level. $\mathrm{H}$ atoms and solvent molecules omitted; $\mathrm{C}$ atoms shown as wireframe for clarity.

All $\mathrm{Ni}^{\prime \prime}$ centres in $\mathbf{1}$ and $\mathbf{2}$ have one solvent molecule and one chloride as monodentate and potentially labile ligands (see computational studies), necessary for the coordination of water molecules as substrate. Moreover, $\mathrm{H}$-bonding facilitates proton transfer processes such as OER. In this regard, methanol acts as $\mathrm{H}$-donor towards the chlorides on the same face of the cubane in 1, with 05 through 08 at distances of 3.006-3.092 $\AA$ to $\mathrm{Cl} 1-\mathrm{Cl} 4$; the corresponding $\mathrm{O}-\mathrm{H}^{\prime \cdots} \mathrm{Cl}$ angles range from 163 to $172^{\circ}$ (Table S2 and Fig. S5). In 2, $\mathrm{H}_{2} \mathrm{O}$ plays the role of $\mathrm{H}$-donor towards the adjacent chlorides at distances ranging from 3.017 to $3.083 \AA$, and $\mathrm{O}-\mathrm{H} \cdot \mathrm{Cl}$ angles from 150 to $168^{\circ}$ (Table S3 and Fig. S6).

Cyclic voltammetry (CV) of $\mathbf{1}$ and $\mathbf{2}$ in DMF reveals irreversible oxidation waves at anodic peak potentials $\left(E_{\mathrm{ap}}\right)$ of 1.15 and $1.09 \mathrm{~V}$ vs $\mathrm{Ag} / \mathrm{AgCl}$ (Figs. S7 and S13). Comparison of the currents observed for $\mathbf{1}$ and $\mathbf{2}$ vs that of ferrocene as internal standard at the same concentration of the cubanes indicates multi-electron processes (Figs. S8 and S14). In aqueous phosphate buffer $(\mathrm{K}-\mathrm{Pi})$ at $\mathrm{pH} \mathrm{7,} \mathrm{irreversible} \mathrm{peaks} \mathrm{are} \mathrm{also}$ detected (Fig. 2). The high currents are indicative of a catalytic process, with onset potentials determined at $0.15 \mathrm{mM}$ as shown in Figs. S11 and S17, and overpotentials $\eta=950$ and $900 \mathrm{mV}$ vs RHE at $\sim 0.7 \mathrm{~mA} \mathrm{~cm}{ }^{-2}$ ( $\eta=210$ and $160 \mathrm{mV}$ vs NHE) for $\mathbf{1}$ and $\mathbf{2}$, respectively. These values are lower than the one example of nickel cubanes previously reported as WOC, ${ }^{12}$ while a related $\mathrm{Ni}_{4} \mathrm{O}_{4}$ was reported as having no activity. ${ }^{13} \mathrm{~A}$ linear dependence of the current relative to the concentration of 1 and 2 in the range $0.05-0.30 \mathrm{mM}$ is consistent with a pseudo-first-order rate constant, with $k_{o b s}=2.05$ and $1.18 \mathrm{~s}^{-1}$ respectively, corresponding to the turnover frequencies (TOF) at single-site catalysts. ${ }^{14}$

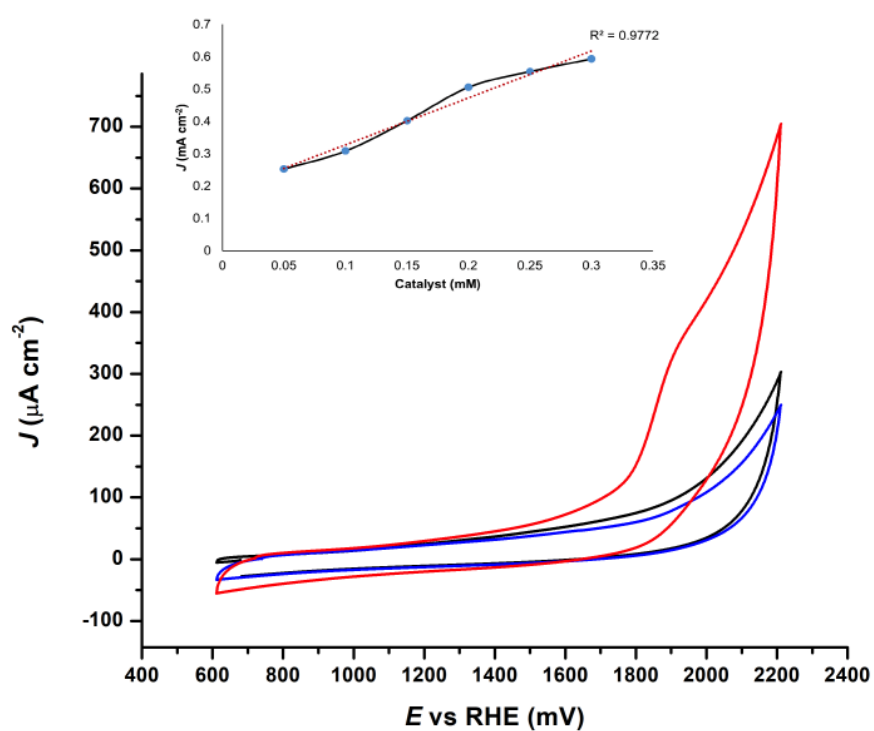

Fig. $2 \mathrm{CV}$ of $0.1 \mathrm{M} \mathrm{K}-\mathrm{Pi} \mathrm{pH} 7$ (black trace); $0.15 \mathrm{mM} 1$ in K-Pi (red trace), and clean K-Pi with working electrode after removal from solution of 1 (blue trace, all CVs at scan rate $100 \mathrm{mV} \mathrm{s}^{-1}$ ). Inset: current dependence on the concentration of 1 .

Reuse of the glassy carbon working electrode in fresh buffer after electrolysing solutions of $\mathbf{1}$ or $\mathbf{2}$ does not show electrocatalytic response (Fig. 2, blue trace). This indicates that $\mathrm{Ni}$-containing deposited materials are not responsible for heterogeneous catalysis. Further support for the integrity of the molecular complexes was provided by $\mathrm{FAB}^{+} \mathrm{MS}$, showing the same fragmentation pattern of 1 before (Fig. S1a) and after (Fig. S1b) electrolysis. Additionally, scanning electron microscopy (SEM) on a planar graphite working electrode before and after controlled potential electrolysis of $0.15 \mathrm{mM} 1$ and $\mathbf{2}$ in $\mathrm{K}-\mathrm{Pi}$ evidenced no deposition after 30 min (Figs. S18S20). ${ }^{8 d}$ UV-Vis absorption spectra of $0.15 \mathrm{mM}$ solutions of 1 and 2 in $0.1 \mathrm{M} \mathrm{K}-\mathrm{Pi}$ were measured before and after electrolysis, with no significant changes (Figs. S21 and S22). Lastly, successive CV scans of $0.15 \mathrm{mM}$ of 1 and $\mathbf{2}$ in $0.1 \mathrm{M} \mathrm{K-Pi}$ at $\mathrm{pH} 7$ showed no increase in catalytic current that may be ascribed to deposition of a heterogenous catalyst (Figs. S23 and S24). All these experiments are consistent with a homogeneous catalytic process by the robust $\mathbf{1}$ and $\mathbf{2}$, which is 
not affected by the presence of phosphate at different concentrations (Figs. S25a and S26). In fact, the electrochemical response is identical in borate buffer at $\mathrm{pH} 8.5$ (Fig. S25b).

Electrochemical measurements in $\mathrm{D}_{2} \mathrm{O} \mathrm{K}-\mathrm{Pi}$ buffer allowed determination of a kinetic isotope effect (KIE), affording values of 0.7 and 1.4 for $\mathbf{1}$ and 2, respectively (Figs. S27 and S28). This is consistent with observations involving two proximal metaloxygen moieties during $\mathrm{O}-\mathrm{O}$ bond formation in the ratelimiting step (I2M mechanism). ${ }^{15}$ A relatively small KIE suggests that primary $\mathrm{H} / \mathrm{D}$ isotope effects that would directly involve $\mathrm{O}$ $\mathrm{H}$ bonds is not likely. ${ }^{3 \mathrm{c}, 16-19}$ Secondary effects, such as protons involved within hydrogen bond networks, ${ }^{20-23}$ could contribute to the extent measured. For comparative purposes, the monometallic complex [bis(2-(1-methylbenzimidazol-2yl)ethyl)amine $\mathrm{NiCl}_{2}$ (3) featuring a tridentate benzimidazolebased ligand was employed in analogous electrochemical measurements. $C V$ in DMF reveals $E_{\text {ap }}$ at 1.10 vs $\mathrm{Ag} / \mathrm{AgCl}$, while in $\mathrm{K}-\mathrm{Pi}$ at a concentration of $0.28 \mathrm{mM}$ to reach comparable current densities to those observed for $\mathbf{1}$ and $\mathbf{2}$, an overpotential $\eta=1.0 \mathrm{~V}$ vs RHE and KIE $=1.7$ (Figs. S29-S33) was determined. This points to a cooperative effect in $\mathbf{1}$ and $\mathbf{2}$ that is absent in monometallic $\mathbf{3}$. The overall behaviour of the cubanes is analogous to that of related homogeneous monometallic $\mathrm{Ni}$ systems previously reported as water oxidation electrocatalysts, and differs from $\mathrm{Ni}\left(\mathrm{NO}_{3}\right)_{2}$ that serves as precursor for $\mathrm{NiO}$ as heterogeneous catalyst. ${ }^{24}$ Confirmation of dioxygen formation during the electrocatalytic processes mediated by the cubanes was obtained by controlled potential electrolysis at $1.5 \mathrm{~V}$ to ensure production of $\mathrm{O}_{2}$ in K-Pi by Clark electrode measurements (Figs. S34 and S35).

To gain insight on the mechanism of water oxidation, DFT calculations were carried out on $\mathbf{1}$ and $\mathbf{2}$ by gas phase optimisation of geometric parameters with the BP86 functional, and subsequently in water. Standard deviations are in the range of DFT precision, 0.035-0.043 $\AA$ and $1.5-1.6^{\circ}$ for bond lengths and angles of $\mathbf{1}$ and $\mathbf{2}$, respectively (ESI Figs. S38S40, S50-S52 and Tables S7-S9, S19-S21). Single-point broken symmetry calculations confirmed the high-spin nature of the electronic ground state, with weak ferromagntic coupling among the $\mathrm{Ni}^{\prime \prime}$ ions, as expected given the average $\mathrm{Ni}-\mathrm{O}-\mathrm{Ni}$ angle of $99^{\circ}$ (Fig. S43 and Tables S10-S11, S22-S23). ${ }^{9,25-27}$ Cooperativity among metal centres for $\mathrm{O}-\mathrm{O}$ bond formation during OER has been invoked in related systems, and a reasonable sequence would require initial ligand exchange. First, substitution of $\mathrm{MeOH}$ by $\mathrm{H}_{2} \mathrm{O}$ in $\mathbf{1}$ is calculated to be exothermic by $-7.1 \mathrm{kcal} \mathrm{mol}^{-1}$ (Figs. S44, S45 and Tables S12S13). Water molecules at adjacent $\mathrm{Ni}$ centres requires $\mathrm{Cl}^{-}$ exchange for $\mathrm{H}_{2} \mathrm{O}$, estimated at 2.8 and $1.6 \mathrm{kcal} \mathrm{mol}^{-1}$ for $\mathbf{1}$ and 2 (Scheme 2, Figs. S46, S47, S55, S56 and Tables S14-S15, S24S25). Oxidation of one nickel ion per water-substituted cubane $\left[\left(\mu_{3}-\mathrm{L}^{\mathrm{n}} \mathrm{O}\right)_{4} \mathrm{Ni}_{4} \mathrm{Cl}_{3}\left(\mathrm{H}_{2} \mathrm{O}\right)_{5}\right]^{+}$to formally $\mathrm{Ni}^{\prime \prime \prime}$ in $\left[\left(\mu_{3}-\right.\right.$ $\left.\left.\mathrm{L}^{\mathrm{n}} \mathrm{O}\right)_{4} \mathrm{Ni}_{4} \mathrm{Cl}_{3}\left(\mathrm{H}_{2} \mathrm{O}\right)_{5}\right]^{2+}$ was calculated at $E=1.16$ and $1.31 \mathrm{~V}$ (vs $\mathrm{RHE})$, which are reasonably close to the experimentally determined onset potentials for OER by 1 and 2 (Figs. S48, S57 and Tables S16, S17, S26, S27). Next, exergonic deprotonation of a water molecule coordinated to the formally $\mathrm{Ni}^{\text {III }}$ centre would result in a $\mathrm{Ni}^{\prime \prime \prime}-\mathrm{OH}$ moiety, calculated at $\Delta \mathrm{G}=-31.5$ (1) and $-16.1 \mathrm{kcal} \mathrm{mol}^{-1}$ (2) with $\mathrm{HPO}_{4}{ }^{2-}$ as base at $\mathrm{pH} 7$ (Figs. S49, S58 and Tables S18, S28, S29). Sequential electron /proton transfer (ET/PT) steps would lead to oxo/hydroxo ligands at
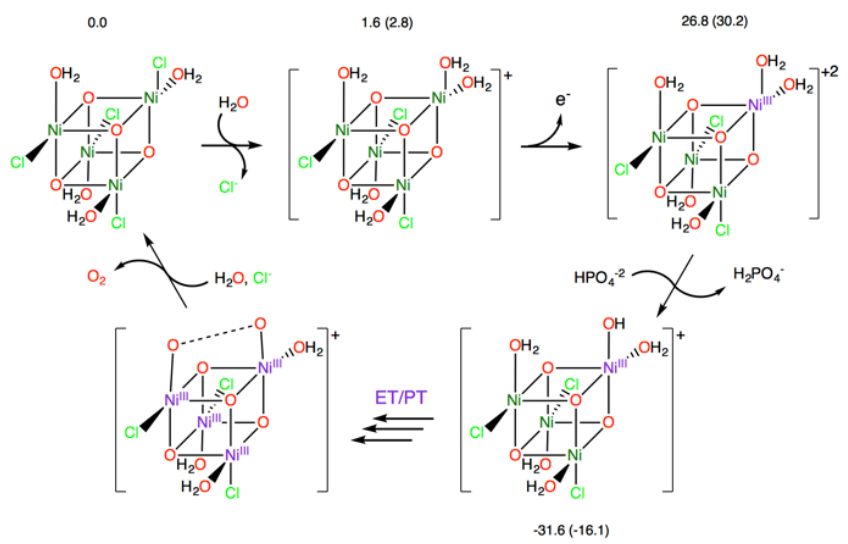

adjacent $\mathrm{Ni}$ centres, and ultimately to $\mathrm{O}_{2}$ evolution as depicted in the proposed I2M mechanism in Scheme 2.

Scheme 2 Proposed I2M mechanism for $\mathrm{O}-\mathrm{O}$ bond formation based on experimental data and DFT calculations. Free energy changes for $\mathbf{1}$ and (2) are indicated in $\mathrm{kcal} \mathrm{mol}^{-1}$ (Fig. S59).

Experimental support for the initial oxidation was provided by low-temperature ESR spectroscopy: reaction of $\mathbf{1}$ with one equiv. of ceric ammonium nitrate in DMF at $77 \mathrm{~K}$ resulted in a weakly anisotropic ESR signal that was simulated considering a single paramagnetic species, leading to three different principal $g$ values at $g_{1}=2.045, g_{2}=2.053, g_{3}=2.061$ and ${ }^{14} \mathrm{~A}_{\mathrm{N}}$ $=25 \mathrm{MHz}$. The $g$ values are consistent with a Ni'"-centred $S=1 / 2$ species (Fig. 3) ${ }^{28}$ and in good agreement with the DFT findings regarding the computed ESR parameters for 1 (Table S30);

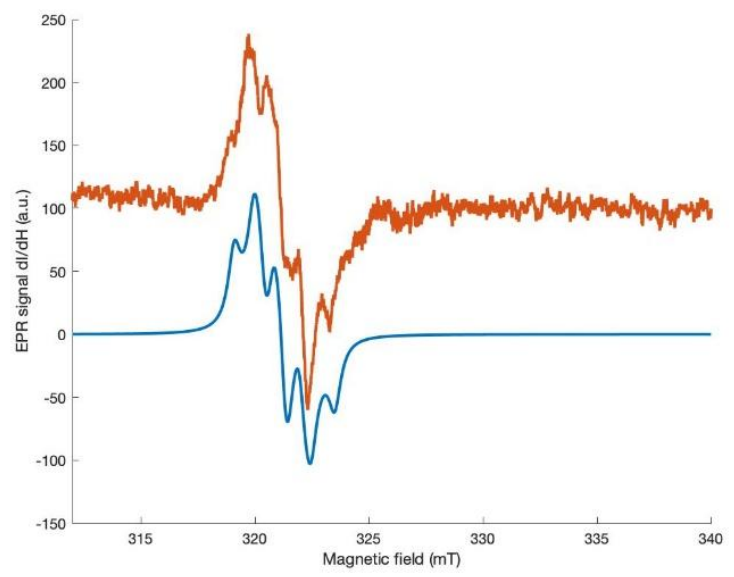

oxidation of $\mathbf{2}$ afforded a weak signal similar to that observed for 1.

Fig. 3 Simulated (blue) and experimental (orange line) $c w$ X-band ESR spectra of $1 \mathrm{mM}$ complex 1 in DMF at $\mathrm{T}=77 \mathrm{~K}$.

In summary, the robust nickel cubanes $\mathbf{1}$ and $\mathbf{2}$ can be easily prepared in good yields from readily available starting 
materials under ambient conditions. The tetranuclear complexes are active in electrocatalytic water oxidation at neutral $\mathrm{pH}$. Extension of this self-assembly strategy for the preparation of other water oxidation catalysts with benzimidazole-based ligands and earth-abundant metals is currently underway.

A. C. García-Álvarez and S. Gamboa-Ramírez contributed in investigation, methodology, analysis, and writing; D. MartínezOtero in crystallographic data collection and analysis; M. Orio and I. Castillo in conceptualisation, funding acquisition, project administration, supervision and writing. There are no conflicts to declare.

\section{Notes and references}

\# The authors thank L. Velasco and J. Pérez for FAB MS, M. P. Orta for combustion analysis, V. Gómez-Vidales and S. Bertaina for EPR, R. Patiño for IR, Prof. Jorge Tiburcio and Geiser Cuéllar at Cinvestav for ESI MS. We gratefully acknowledge financial support from Conacyt (A1-S-8682, beca 336107), Conacyt-ECOS Nord 291247, DGAPA-PAPIIT (IN217020), and the French National Research Agency (CUBISM, grant no. ANR-18 CE092 004001 ).

1 Y. Umena, K. Kawakami, J. R. Shen, N. Kamiya, Nature, 2011, 473, 55.

2 a) G. C. Dismukes, R. Brimblecombe, G. A. N. Felton, R. S. Pryadun, J. E. Sheats, L. Spiccia, G. F. Swiegers, Acc. Chem. Res., 2009, 42, 1935; b) R. Mattheu, P. Garrido-Barros, M. Gil-Sepulcre, M. Z. Ertem, X. Sala, C. Gimbert-Suriñach, A. Llobet, Nat. Rev. Chem., 2019, 3, 331; c) M. D. Kärkäs; B. Åkermark, Dalton Trans., 2016, 45, 14421.

3 a) N. S. Lewis, D. G. Nocera, Proc. Natl. Acad. Sci. U. S. A., 2007, 104, 20142; b) R. Eisenberg, H. B. Gray, Inorg. Chem., 2008, 47, 1697; c) M. D. Kärkäs, O. Verho, E. V. Johnston, B. Åkermark, Chem. Rev., 2014, 114, 11863.

4 a) E. Kim, K. Huang, S. Jegelka, E. Olivetti, NPJ Comput. Mater., 2017, 3, 1120; b) M. G. Mavros, J. J. Shepherd, T. Tsuchimochi, A. R. Mclsaac, T. Van Voorhis, J. Phys. Chem. C, 2017, 121, 15665

5 a) C. W. Coley, W. H. Green, K. F. Jensen, Acc. Chem. Res. 2018, 51, 1281; b) S. Back, K. Tran, Z. W. Ulissi, ACS Catal. 2019, 9, 7651.

6 a) M. D. Symes, Y. Surendranath, D. A. Lutterman, D. G. Nocera, J. Am. Chem. Soc., 2011, 133, 5174; b) P. F. Smith, C. Kaplan, J. E. Sheats, Robinson, D. M.; McCool, N. S.; Mezle, N.; Dismukes, G. C. Inorg. Chem., 2014, 53, 2113; c) A. I. Nguyen, M. S. Ziegler, P. Oña-Burgos, M. Sturzbecher-Hohne, W. Kim, D. E. Bellone, T. D. Tilley, J. Am. Chem. Soc., 2015, 137, 12865.

7 A. N. Ponomaryov, N. Kim, J. Hwang, H. Nojiri, J. Van Tol, A. Ozarowski, J. Park, Z. Jang, B. Suh, S. Yoon, K. Y. Choi, Chem. Asian J., 2013, 8, 1152.

8 a) K. Isele, F. Gigon, A. F. Williams, G. Bernardinelli, P. Franz, S. Decurtins, J. Chem. Soc. Dalton Trans., 2006, 332; b) A. Das, F. J. Klinke, S. Demeshko, S. Meyer, S. Dechert, F. Meyer, Inorg. Chem., 2012, 51, 8141; c) F. Song, K. Al-Ameed,
M. Schilling, T. Fox, S. Luber, G. R. Patzke, J. Am. Chem. Soc., 2019, 141, 8846; d) G. Azadi, Z. Zand, Y. Mousazade, R. Bagheri, J. Cui, Z. Song, R. Bikas, K. Wozniak, S. I. Allakhverdiev, M. M. Najafpour, Int. J. Hydrog. Energy 2019, 44, 2857.

9 a) X.-Y. Song, Y.-H. Xu, L.-C. Li, D.-Z. Liao, Z.-H. Jiang, Inorg. Chim. Acta, 2007, 360, 2039.

10 M. A. Halcrow, J.-S. Sun, J. C. Huffman, G. Christou, Inorg. Chem., 1995, 34, 4167.

11 C. G. Efthymiou, C. Papatriantafyllopoulou, N. I. Alexopoulou, C. P. Raptopoulou, R. Boča, J. Mrozinski, E. G. Bakalbassis, S. P. Perlepes, Polyhedron, 2009, 28, 3373.

12 J. Wang, X. Meng, W. Xie, X. Zhang, Y. Fan, M. Wang, J. Biol. Inorg. Chem., 2021, 26, 205.

13 F. Song, R. Moré, M. Schilling, G. Smolentsev, N. Azzaroli, T. Fox, S. Luber, G. R. Patzke, J. Am. Chem. Soc., 2017, 139, 14198.

14 W. S. Gao, J. M. Wang, N. N. Shi, C. N. Chen, Y. H. Fan, M. Wang, New J. Chem., 2019, 43, 4640.

15 M. D. Kärkäs, B. Åkermark, Dalton Trans., 2016, 45, 14421.

16 V. Fourmond, P. A. Jacques, M. Fontecave, V. Artero, Inorg. Chem., 2010, 49, 10338.

17 V. Artero, J. M. Saveant, Energy Environ. Sci., 2014, 7, 3808.

18 A. M. Appel, M. L. Helm, ACS Catal., 2014, 4, 630.

19 C. Costentin, S. Drouet, M. Robert, J. M. Savéant, J. Am Chem. Soc., 2012, 134, 11235.

20 R. S. Khnayzer, V. S. Thoi, M. Nippe, A. E. King, J. W. Jurss, K. A. El Roz, J. R. Long, C. J. Chang, F. N. Castellano, Energy Environ. Sci., 2014, 7, 1477

21 L. Chen, G. Chen, C. F. Leung, S. M. Yiu, C. C. Ko, E. Anxolabéhère-Mallart, M. Robert, T. C. Lau, ACS Catal., 2015, 5,356

22 Z. Han, W. R. McNamara, M. S. Eum, P. L. Holland, R. Eisenberg, Angew. Chem. Int. Ed., 2012, 51, 1667.

23 Y. Xu, X. Yin, Y. Huang, P. Du, B. Zhang, Chem. Eur. J., 2015, 21, 4571.

24 D. Wang, C. O. Bruner, Inorg. Chem., 2017, 56, 13638.

25 J. Mayans, A. A. Athanasopoulou, A. T. Pham, M. FontBardia, E. C. Mazarakioti, M. Pilkington, T. C. Stamatatos, A. Escuer, Dalton Trans., 2019, 10427.

26 H. A. Rudbari, F. Lloret, M. Khorshidifard, G. Bruno, M. Julve, RSC Adv., 2016, 6, 7189.

27 Q.-L. Zhang, Z.-L. Wu, H. Xu, B. Zhai, Y.-F. Wang, G.-W. Feng, Y.-L. Huang, Z. Anorg. Allg. Chem. 2016, 642, 5, 414.

28 a) F. F. Pfaff, F. Heims, S. Kundu, S. Mebs, K. Ray, Chem. Commun., 2012, 48, 3730; b) M.-C. Kafentzi, M. Orio, M. Réglier, S. Yao, U. Kuhlmann, P. Hildebrandt, M. Driess, A. J. Simaan, K. Ray, Dalton Trans. 2016, 45, 15994. 